\title{
Influence of Different Fuel Agents on the Combustion Synthesis of the Nanostructured $\mathrm{Li}_{1.05} \mathrm{Mn}_{2} \mathrm{O}_{4}$ Oxide
}

\author{
F. A. Amaral*, R. F. Guerra, L. K. Santana, S. C. Canobre \\ Laboratório de Armazenamento de Energia e Tratamento de Efluentes - LAETE, \\ Instituto de Química, Universidade Federal de Uberlândia - UFU, \\ Av. João Naves de Ávila, 2121, CEP 38408-100, Uberlândia, MG, Brasil
}

Received: June 19, 2013; Revised: November 26, 2013

\begin{abstract}
In this work nanostructured $\mathrm{Li}_{1.05} \mathrm{Mn}_{2} \mathrm{O}_{4}$ oxide was obtained by Solution Combustion Synthesis (SCS) using three different fuel agents in order to obtain a unique phase with a crystalline cubic structure belonging to the $F_{\mathrm{d} 3 \mathrm{~m}}$ spatial group. The phase of interest could be obtained, following the order: glycine $\left(\right.$ at $600{ }^{\circ} \mathrm{C}$ for $\left.2 \mathrm{~h}\right)<$ urea $\left(\right.$ at $750{ }^{\circ} \mathrm{C}$ for $\left.2 \mathrm{~h}\right)<$ maleic anhydride $\left(\right.$ at $750{ }^{\circ} \mathrm{C}$ for $4 \mathrm{~h}$ ), with crystallite size in the range from 4.6 to $9.7 \mathrm{~nm}$ (nanometric character) and the unit cell parameter of the calcined samples at $750{ }^{\circ} \mathrm{C}$ for $2 \mathrm{~h}$ were similar to the JCPDS 35-0782 with cubic structure ( $a=8.247$ $\AA$ ). Charge and discharge tests from the samples obtained by glycine fuel (at $750{ }^{\circ} \mathrm{C}$ for $4 \mathrm{~h}$ ) presented the highest experimental specific capacities of $115 \mathrm{~mA} \mathrm{~h} \mathrm{~g}^{-1}$ and $92 \%$ of retention after 10 cycles.
\end{abstract}

Keywords: Solution Combustion Synthesis, cathode, $\mathrm{Li}_{1.05} \mathrm{Mn}_{2} \mathrm{O}_{4}$ spinel, lithium ion batteries

\section{Introduction}

In the last few decades the proliferation of electronic equipment, as cellular phones and portable microcomputers, has led to an increase in the production of energy storage devices (batteries), smaller, lighter, with good performance ${ }^{1}$, making it vitally important to the life of society. It is in this context that the lithium ion rechargeable systems have, since the beginning of this century, become a major area in the global battery market, as early as 2004, the world production of the devices had reached the order of 700 million units ${ }^{2}$ since they offer higher density of energy as compared with the others.

The material mostly used in the anode is the lithium graphite $\left(\mathrm{LiC}_{6}\right)$ and in the cathode are the intercalation compounds of transition metals, in general, the $\mathrm{LiCoO}_{2}{ }^{3}$.

However, the $\mathrm{LiMn}_{2} \mathrm{O}_{4}$ spinel with cubic structure belonging to the $F_{\mathrm{d} 3 \mathrm{~m}}$ spatial group has been the objective of many studies since it shows itself as a prominent material for such applicability. This occurs because it presents various advantages as related to the candidates such as: intercalation capacity of lithium ions (2 lithium ions per unit formula, one in the $3 \mathrm{~V}$ region and the other in the $4 \mathrm{~V}$ region $v s$. $\left.\mathrm{Li} / \mathrm{Li}^{+}\right)^{4}$. Besides, it presents a greater abundance and less toxicity than $\mathrm{LiCoO}_{2}{ }^{5}$. Among the several possible routes of synthesis, one that highlights is the Solution Combustion Synthesis (SCS) which has a high energy efficiency that presents itself as advantages: simplicity, low cost and the obtainment of nanometric dusts with uniform distribution of particle size ${ }^{6}$. The investigation of different fuel agents is based on the fact that they present different interaction with the reactants changing the morphology aspect of the synthesized oxide and depending on the amount of generated heat, it makes it possible to obtain a more crystalline phase ${ }^{7}$. This work

*e-mail: fabioamaral@iqufu.ufu.br intended to investigate the Solution Combustion Synthesis (SCS) of the $\mathrm{Li}_{1,05} \mathrm{Mn}_{2} \mathrm{O}_{4}$ nanoparticles ${ }^{4}$, from different fuel agents, with structural and morphological characteristics that facilitated the intercalation and deintercalation of lithium ions. The SCS takes into account the basic chemistry of the propellants which considers each element having its valence in the gases evolved in the reaction $\left(\mathrm{CO}_{2}, \mathrm{H}_{2} \mathrm{O}\right.$ and $\left.\mathrm{N}_{2}\right)$. In this case, it is the oxygen element oxidizing, carbon is a reducing agent and nitrogen is inert. Thus, the valences of oxygen, carbon, hydrogen and nitrogen are, respectively, -2 , $+4,+1$ and $0^{[8]}$. The combustion heats of fuels investigated agents are increasing in the following order: urea $<$ glycine $<$ Maleic Anhydride. The combustion heats of the urea, glycine and maleic anhydride, respectively, are 10.5, 13.0 and $14 \mathrm{KJ} \mathrm{g}^{-1[9]}$. In this work we developed a systematic investigation of the nature of these three fuel agents in the synthesis of the lithiated manganese oxides.

\section{Material and Methods}

The precursors of the method, metal nitrates (Lithium Nitrate $-\mathrm{LiNO}_{3}$ and Manganese Nitrate $\left.\mathrm{Mn}\left(\mathrm{NO}_{3}\right)_{2} \cdot 6 \mathrm{H}_{2} \mathrm{O}\right)$ and fuel agent - Urea $\left(\mathrm{NH}_{2}\right)_{2} \mathrm{CO}$, Glycine (Acetic Amino Acid) $\mathrm{C}_{2} \mathrm{H}_{5} \mathrm{NO}_{2}$ or Maleic Anhydride $\mathrm{C}_{4} \mathrm{H}_{2} \mathrm{O}_{3}-$ were solubilized in deionized water and heated on a heating plate until the obtainment of a homogeneous solution. Then, it was submitted to the heating in a muffler type oven until a large amount of gases came off and released until auto-ignition occurs (combustion). The resulting dusts were calcined at varied times and temperatures $\left(500{ }^{\circ} \mathrm{C}\right.$, $600{ }^{\circ} \mathrm{C}, 700^{\circ} \mathrm{C}$ or $750^{\circ} \mathrm{C}$ for $0.5 \mathrm{~h} ; 1 \mathrm{~h} ; 2 \mathrm{~h}$ or $4 \mathrm{~h}$ ) up to the obtainment of the single phase characteristic of the spinel. The proportions between the oxidizing and reducing agents were calculated based on the fuel by chemistry method of 
the Thermodynamic Modeling of the Solution Combustion Synthesis ${ }^{6}$. A calcined sample by solid state reaction at 750 ${ }^{\circ} \mathrm{C}$ for $24 \mathrm{~h}$ was used as reference. The particle size of the calcined oxides was controlled by deagglomeration in a \#325 mesh sieve (smaller than $45 \mu \mathrm{m}$ ).

The powders were also characterized by X-ray diffraction analysis (XRD) using a Shimadzu model XRD $6000, \mathrm{Cu}-\mathrm{K} \alpha$ radiation $(\lambda=1,5418 \AA)$, voltage $40 \mathrm{kV}$ and current $30 \mathrm{~mA}$. The speed step was $0.02^{\circ} \mathrm{s}^{-1}$ and a range of $10^{\circ} \leq 2 \theta \leq 80^{\circ}$. Samples are prepared from the sample powder, pressing the solid with a glass plate in aluminum sample holder. The average crystallite size - using the Scherrer Equation ${ }^{10}$ - and FWHM were calculated from the widening of the basal X-ray reflection peak $\left(d_{111}\right)$ and the unit cell parameter were calculated using the Unit Cell Win program, with the adjustment of the diffractogram peaks previously made on the Peak Fit software.

The micrographies were obtained using a Hitachi electronic scanning microscope, Model 3000, with 1000, 3000 and 5000 amplifications. The B.E.T surface areas of the catalysts and supports were determined in a Micromeritics ASAP 2020 apparatus, from the nitrogen adsorption isotherms at $77 \mathrm{~K}$. Prior to the analysis the samples were degasified overnight at $150{ }^{\circ} \mathrm{C}$ with a heating rate of $10{ }^{\circ} \mathrm{C} \mathrm{min}^{-1}$. For the electrochemical evaluation electrodes were made with $85 \%(\mathrm{~m} / \mathrm{m})$ of the synthesized oxide, $10 \%$ of black acetylene VULCAN XC 72-GP 2800 (Cabot USA) and 5\% of Polyvinylidene Fluorite (PVDF) (Aldrich; P.A.) dispersed in cyclohexanone (Aldrich; P.A.). The electrodes of the synthesized oxide were then submitted to cyclic voltammetry between -0.5 and $1.3 \mathrm{~V} v s$. $\mathrm{Ag} / \mathrm{AgCl}$ and scanning speed of $0.5 \mathrm{mV} \mathrm{s}^{-1}$, using counter electrode of a disassembled cellular telephone battery $\left(\mathrm{LiC}_{6}\right)$, made on ethylene carbonate/ dimethylene carbonate (EC/DMC) $\mathrm{LiClO}_{4} 1 \mathrm{~mol} \mathrm{~L}^{-1}$, using an Autolab potentiostat $302 \mathrm{~N}$, interfaced with a microcomputer using software GPES version 4.9 .

The chronoamperometry tests to evaluate the cathode charge storage capacity were carried out in a anodic/ cathodic current density of $51 \mu \mathrm{A} \mathrm{cm} \mathrm{cm}^{-2}$ and $102 \mu \mathrm{A} \mathrm{cm}{ }^{-2}$, respectively, over the potential range 3.30-4.35 Vvs. $\mathrm{Li} / \mathrm{Li}^{+}$, in a dry Labconco chamber, Model 50600) with controlled humidity $\left(<10 \mathrm{ppm}\right.$ of $\left.\mathrm{H}_{2} \mathrm{O}\right)$ by passage of argon (Air Liquid, $99.999 \%)$.

\section{Results and Discussion}

Figure 1 illustrates the X-ray diffractograms of the samples obtained for the three fuel agents used in the stoichiometric proportion in relation to the metal nitrates, calcined for $2 \mathrm{~h}$, at varied temperatures for analysis of this parameter in the obtainment of the spinel phase of interest. One verifies that when urea was used as a fuel agent, the $\mathrm{X}$-ray diffractogram of the calcined sample at $600{ }^{\circ} \mathrm{C}$ for $2 \mathrm{~h}$ (Figure 1a) was different from the other for the same temperature and time, showing a phase transition to the cubic structure of the spinel, so that for calcined samples at temperatures lower than $750{ }^{\circ} \mathrm{C}$, additional peaks were observed causing that such reflections could not be indexed in a unique crystallographic card, possibly for being an oxide mixture. On the other hand, in the diffractograms of the samples where glycine was used (Figure 1b), reflections were observed agreeing with those of the crystallographic card JCPDS 35-0782, even at lower calcination temperatures $\left(600{ }^{\circ} \mathrm{C}\right)$, indicating the obtainment of stoichiometric spinel free from other phases, so that phase transition was not evidenced for this fuel agent. As regards at the maleic anhydride (Figure 1c), the X-ray diffractograms showed more reflections than those relative to the stoichiometric spinel, characteristic of phase mixture, causing that such reflections could not be indexed in a unique crystallographic card. However, all x-ray diffractograms of the calcined sample at $750{ }^{\circ} \mathrm{C}$ for $4 \mathrm{~h}$ presented a profile similar to the standard card for the stoichiometric spinel as shown in the Figure 2.

The variation in the calcination time of the samples was not so significant (for the investigated times) for the obtainment of structures with higher crystallinity when compared with the previous analysis of temperature. Thus, the FWHM parameter (Full Width - Half Maximum) was used to monitor the crystallinity of the oxides. It was observed in the Figure 3 that FWHM shows that the temperature rise contributes to the obtainment of a more crystalline structure, as evidenced by decrease of the FWHM. The unit cell parameter was calculated to monitor the amount of lithium ions in the oxide structure until the obtainment of the stoichiometric $\mathrm{LiMn}_{2} \mathrm{O}_{4}$ structure. According to the unit cell parameter, a general trend was observed for the first two cases (urea and glycine): there is

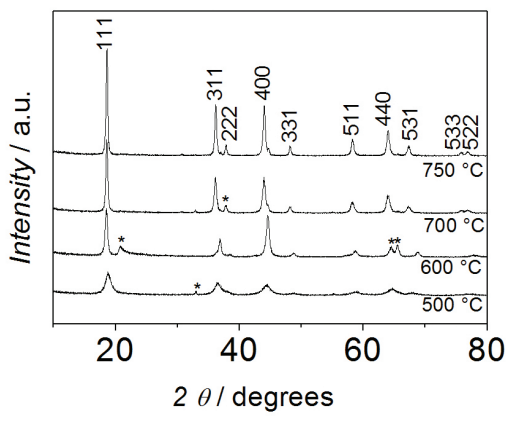

(a)

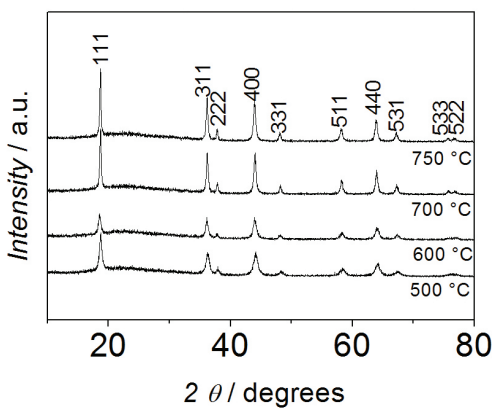

(b)

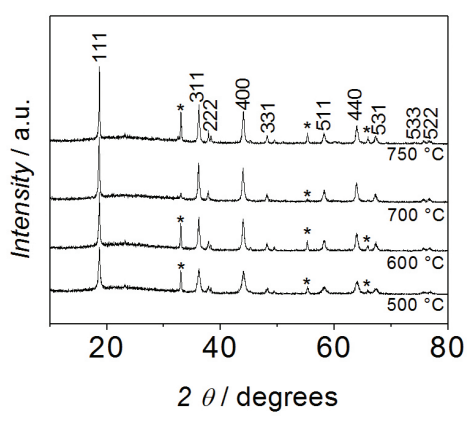

(c)

Figure 1. X-ray diffratograms of calcined samples for $2 \mathrm{~h}$ at different temperatures with fuel agent: a) urea; b) glycine and c) maleic anhydride. 
a greater increase as the calcination temperature increases, whereas for the maleic anhydride a smaller variation was observed, suggesting a faster intercalation of lithium ions for the last fuel agent. It was also observed for all cases that the unit cell parameter showed a good agreement with the indexed reference value of the JCPDS card (8.247 $\AA$ ), indicating the obtainment of the stoichiometric spinel. The $\mathrm{LiMn}_{2} \mathrm{O}_{4}$ obtained by this methodology showed a higher unit cell parameter that those obtained by reaction in solid state at $750{ }^{\circ} \mathrm{C}$ for $24 \mathrm{~h}(8.299 \AA)$ suggesting a greater intercalation of lithium ions.

The crystallite sizes calculated by Scherrer equation for the calcined samples at $750{ }^{\circ} \mathrm{C}$ for $2 \mathrm{~h}$ using urea, glycine and maleic anhydride were: $4.61,6.57$ and $9.71 \mathrm{~nm}$, respectively, confirming the nanometric character of the synthesized oxide particles. The Figure 4 showed the dust morphology obtained for calcined $\mathrm{Li}_{1.05} \mathrm{Mn}_{2} \mathrm{O}_{4}$ at $750{ }^{\circ} \mathrm{C}$ for $2 \mathrm{~h}$, since this calcination condition showed a more uniformity as regards the structural characteristics, allowing better comparison of the morphologic properties.

From the analysis of the micrographies shown in Figure $4 \mathrm{a}$ it was possible to assert that calcined sample, using urea fuel agent, presented a more uniform distribution of the particles than for other samples, with grains smaller than $10 \mu \mathrm{m}$, globular format and no signs of sintering, there by facilitating to the intercalation and deintercalation of lithium ions in the structure of the oxide. It is possible to notice that in all cases even though the agglomerates were

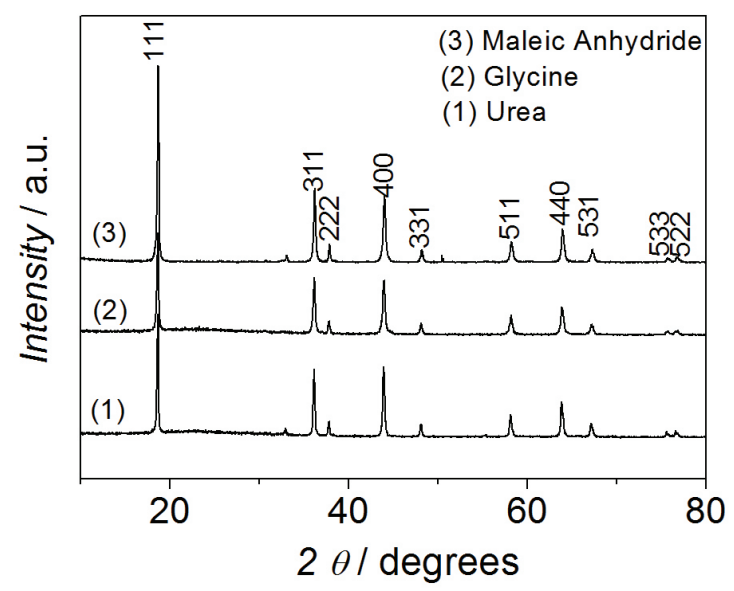

Figure 2. X-ray diffratograms of the calcined samples at $750{ }^{\circ} \mathrm{C}$ for $4 \mathrm{~h}$ using as fuel agent: 1) urea; 2) glycine and 3) maleic anhydride. formed by very small particles due to the high reactivity of the precursor solution, by consequence of the high surface tension of the oxide particles agglomerates are found bonded by weak Van der Walls forces, which is possibly related with the less gas evolution observed during the sample synthesis with urea as fuel agent. The morphology of the synthesized oxide from glycine (Figure $4 b$ ) shows the formation of the porous sponge-like agglomerates, with irregular shape and varied sizes, smaller than $20 \mu \mathrm{m}$, due to the higher evolution of the gases. These agglomerates showed a dense aspect, showing that they are formed by strongly linked particles (sintered) with strong state of aggregation. An important aspect in the aggregation phenomenon of nanoparticles is that it is attributed to the growth by coalescence of the cores, so that the resulting particles, aggregate by means of a sintering process in which there is a reduction of the free energy of the system surface, leading to a material with a smaller surface area by the reduction of the interface of the compacted dust with the medium ${ }^{11}$.

In this work the mean values of surface area (B.E.T.) were around $8.88 \mathrm{~m}^{2} \mathrm{~g}^{-1}$, much bigger than the ones observed for the same oxide obtained by reaction in solid state with calcinations at $750{ }^{\circ} \mathrm{C}$ for $24 \mathrm{~h}\left(2.23 \mathrm{~m}^{2} \mathrm{~g}^{-1}\right)$.

On the other hand, in the micrography shown in Figure $4 \mathrm{c}$ an increased similarity of the oxide surfaces obtained from the maleic anhydride as fuel agent is seen with that of the oxide obtained using glycine, both showing varied distribution of the particle size. In addition, these oxides show an increased porosity, which facilitates the intercalation process of the lithium ions along successive charge/discharge cycles corroborating with well-defined voltammetric profiles and with good reversibility of the redox processes of the cathodes prepared from these samples, as will be discussed next. After structural morphological characterization, cyclic voltammetry electrochemical tests were carried out to evaluate the redox profiles of the cathodes prepared from synthesized oxides, having these samples been calcined at $750{ }^{\circ} \mathrm{C}$ for $2 \mathrm{~h}$ and a single stage at lower temperature and calcination time in the XRD diffractograms. From Figure 5a it is possible to apprehend that the cathode made from the sample in which urea did not present an identical profile as expected since in the 0.9 and $1.2 \mathrm{~V}$ region the extraction process did not occur in two well-defined phases. That is probably because of a small ordering of the crystallographic sites. In the Figure $5 \mathrm{~b}$ and $\mathrm{c}$ it was observed that the cathodes showed well-defined voltammetric profiles and with a good

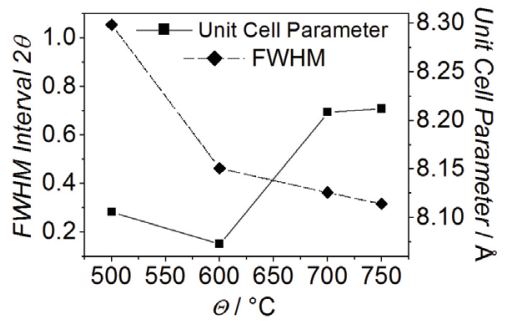

(a)

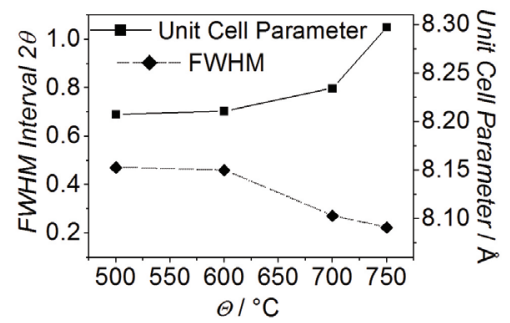

(b)

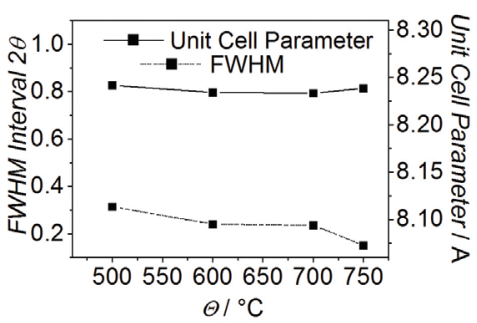

(c)

Figure 3. FWHM Interval $2 \theta$ Chart and Unit Cell Parameter in function of the calcination temperature for samples calcined for $2 \mathrm{~h}$ in the stoichiometric proportion when the fuel agent used was: a) urea; b) glycine and c) maleic anhydride. 


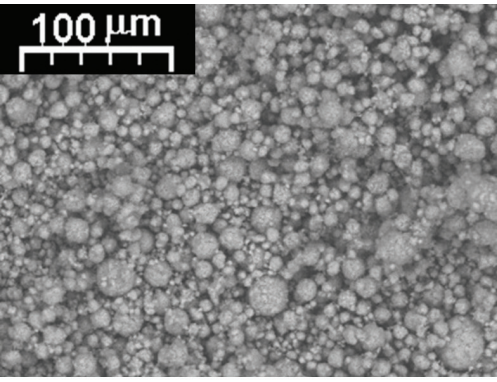

(a)

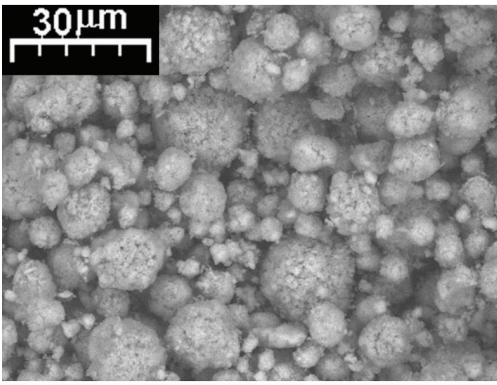

(a)

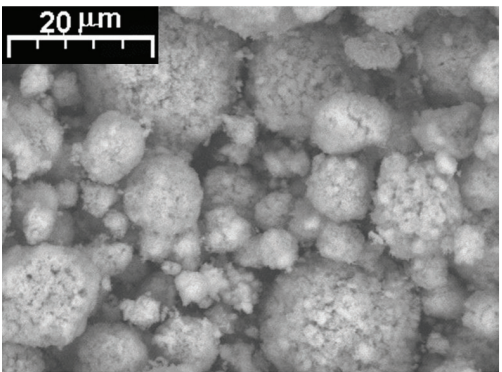

(a)

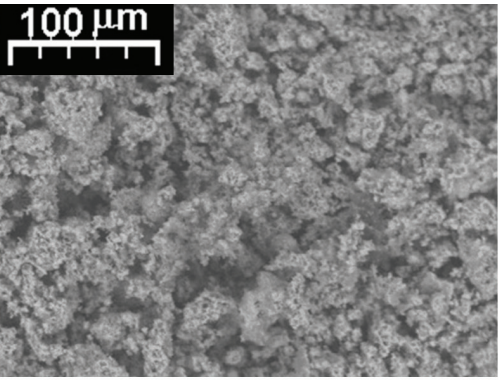

(b)

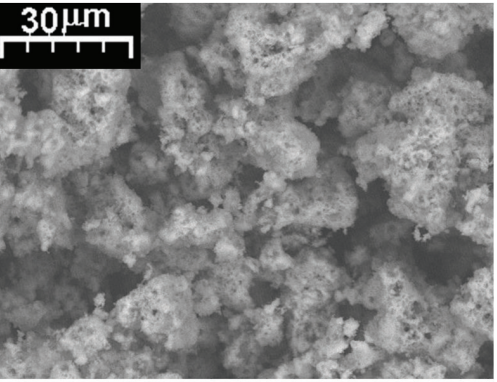

(b)

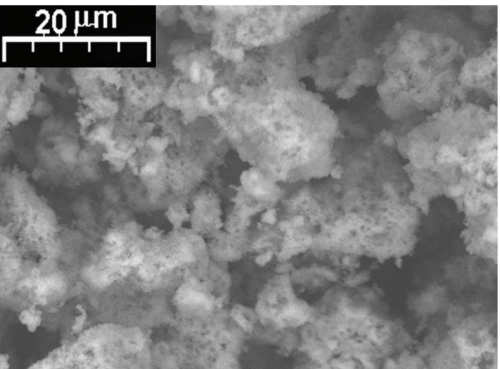

(b)

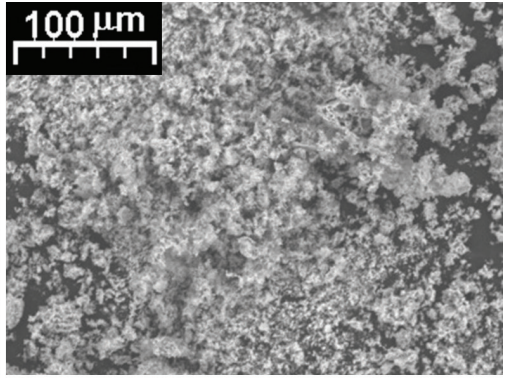

(c)

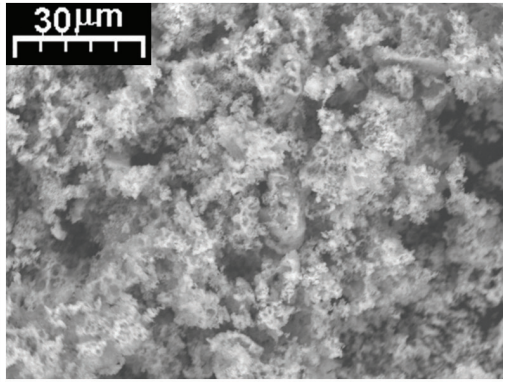

(c)

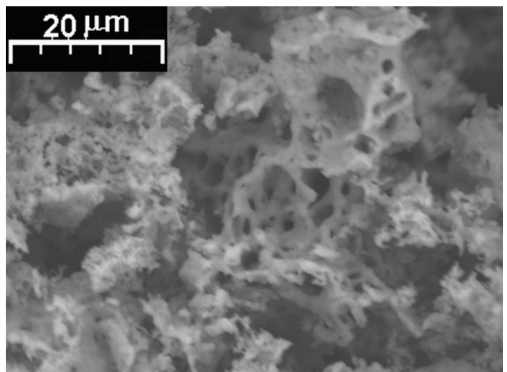

(c)

Figure 4. Micrographies of the $\mathrm{Li}_{1.05} \mathrm{Mn}_{2} \mathrm{O}_{4}$ spinel oxide obtained by combustion calcined at $750{ }^{\circ} \mathrm{C}$ for $2 \mathrm{~h}$ using as fuel agent: a) urea; b) glycine and c) maleic anhydride.

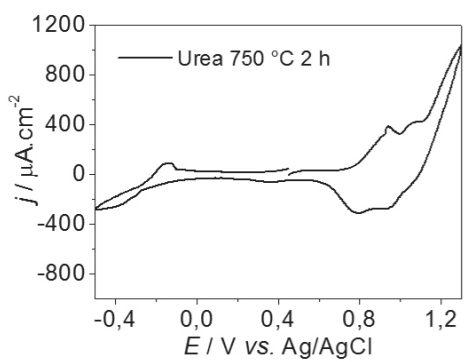

(a)

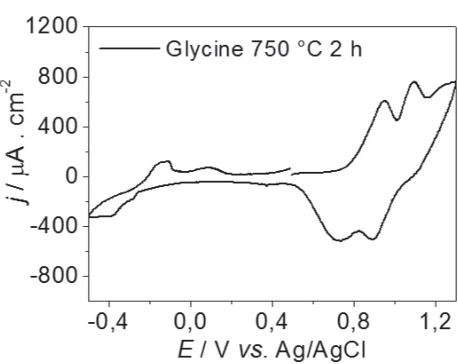

(b)

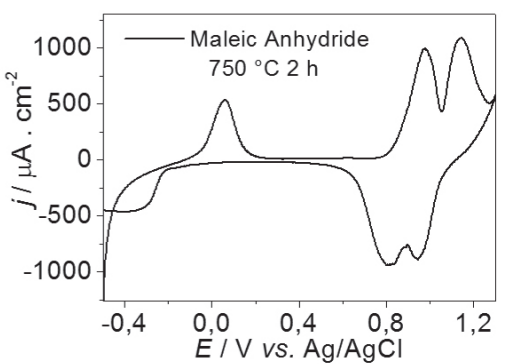

(c)

Figure 5. Voltammetric profiles of the cathodes prepared from oxide samples obtained at $750{ }^{\circ} \mathrm{C}$ for $2 \mathrm{~h}$ when the fuel agent used was: a) urea; b) glycine and c) maleic anhydride; made on EC/DMC $\mathrm{LiClO}_{4} 1 \mathrm{~mol} \mathrm{~L}^{-1}$ at $0.5 \mathrm{mV} \mathrm{s}^{-1}$.

separation of the direct and reverse scanning peaks, showing that the deepest sites of the oxide are accessible. However, the peak currents observed in the voltammograms shown in the Figure $5 \mathrm{c}$ were larger than those observed in the other voltammograms, suggesting more insertion of the lithium ions in these structures.

The cathodes prepared from all the sample obtained by SCS were firstly submitted to initial charge and discharge tests over the potential range of 3.30-4.35 V vs. $\mathrm{Li} / \mathrm{Li}^{+}$. The specific capacity values obtained during 10 charge and discharge cycles for cathodes prepared from different fuel agents investigated in this work are presented in the Figure 6. After the tenth cycle, the calcined samples at $750{ }^{\circ} \mathrm{C}$ for $2 \mathrm{~h}$ presented initial specific capacity values decreasing in the following order (glycine $\sim$ maleic anhydride $>$ urea), suggesting that the higher porosity observed in these oxides 


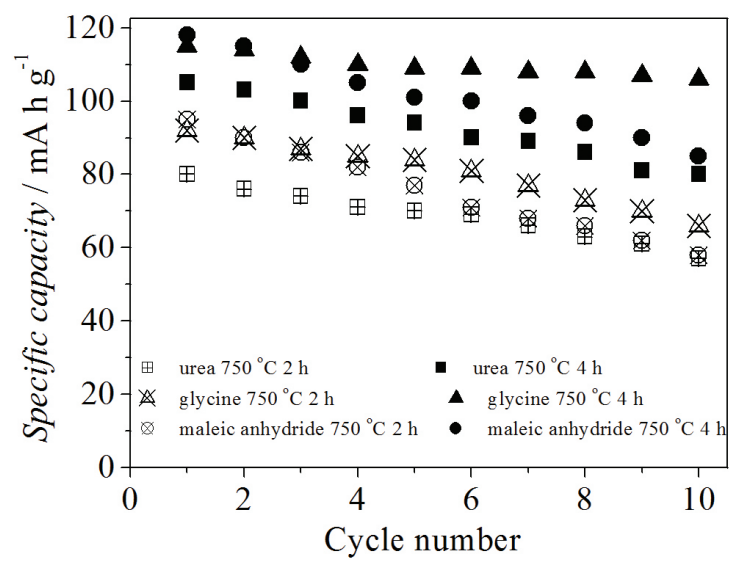

Figure 6. Specific capacities of discharge of the cathodes prepared from oxide samples obtained at $750{ }^{\circ} \mathrm{C}$ when the fuel agent used was: urea; glycine or maleic anhydride; made on EC/DMC $\mathrm{LiClO}_{4}$ $1 \mathrm{~mol} \mathrm{~L}^{-1}$ at $j_{\mathrm{a}}=51 \mu \mathrm{A} \mathrm{cm}{ }^{-2}$ and $j_{\mathrm{c}}=102 \mu \mathrm{A} \mathrm{cm}^{-2}$, cut off $=3.30-$ $4.35 \mathrm{~V}$.

influenced in the lithium-ion intercalation processes in the oxide structure. For the calcined samples at $750{ }^{\circ} \mathrm{C}$ for $4 \mathrm{~h}$, the same order was observed, indicating that the highest discharge capacities obtained for the samples obtained by glycine and maleic anhydride are according to the larger surface area and unit cell parameter similar to that of the stoichiometric spinel. The samples obtained from the glycine fuel agent showed the best retention capabilities over the cycles number ( $92 \%$ after ten cycles). Moreover, the samples obtained in this study showed high specific capacity (80\% of the theory) only for that calcined at $750{ }^{\circ} \mathrm{C}$ for $4 \mathrm{~h}$. Besides, the electrochemical activity displayed by these samples could be obtained by SCS at times and temperatures much lower than those presented in the literature.

Yang et al. proposed the SCS solution methodology for the obtaining of the $\mathrm{LiMn}_{2} \mathrm{O}_{4}$ nanoparticles, using urea as the fuel agent without additional phases at $800{ }^{\circ} \mathrm{C}$ for $24 \mathrm{~h}$. However, they obtained a considerable loss of the specific capacity during the charge and discharge processes (88\% after 640 cycles) ${ }^{6}$. Lu et al. were able to obtain the stoichiometric spinel phase, using urea as fuel agent for calcined sample at $700{ }^{\circ} \mathrm{C}$ for $10 \mathrm{~h}$, however, the obtained unit cell parameter ( $a=8.188 \AA$ ) was relatively distant from the theoretical value $(a=8.247 \AA$ ) and surface area (BET) was $1.8749 \mathrm{~m}^{2} \mathrm{~g}^{-1}$ for a calcination time at $700{ }^{\circ} \mathrm{C}$ for $10 \mathrm{~h}$, considerably smaller than the obtained in our

\section{Refererences}

1. Brodd RJ. Recent Developments in Batteries for Portable Consumer Electronics Applications. Electrochemical Society Interface. 1999; 8:20-23.

2. Lupi C, Pasquali M and Dell'era A. Nickel and cobalt recycling from lithium-ion batteries by electrochemical processes. Waste Management. 2005; 25(2):215-20. http://dx.doi.org/10.1016/j. wasman.2004.12.012

3. Varela H, Huguenin F, Malta M and Torresi RM. Materiais para cátodos de baterias secundárias de lítio. Química work $\left(8.88 \mathrm{~m}^{2} \mathrm{~g}^{-1}\right)^{12}$. Recently, Zhu et al. synthesized $\mathrm{LiMn}_{2} \mathrm{O}_{4}$ nanoparticles using only glycine as the fuel agent and they investigated only the calcination temperature for $10 \mathrm{~h}$, obtaining the best result for calcined oxides at 900 ${ }^{\circ} \mathrm{C}$ by electrochemical and structural characterizations ${ }^{13}$. It is important to note that these calcination times and temperatures are considerably higher than those obtained in this work.

\section{Conclusions}

According to the results obtained in this work, it was possible to obtain a lithiated manganese oxide in the stoichiometric spinel phase with cubic structure by SCS with calcination, using urea, glycine, and maleic anhydride as fuel agents, however it can be obtained at lower calcination temperatures/times following this order of fuel agents: glycine $<$ urea $<$ maleic anhydride. The crystallite size values were obtained in the range between 4.6 and $9.7 \mathrm{~nm}$ (nanometric character). The obtained unit cell parameter showed good agreement as compared with those of the stoichiometric spinel. Besides, with the increase of the calcination temperature and times provided the cathodes with greater insertion and extraction capacities of the lithium ions.

The MEV micrographies showed the sintering of the calcined samples from the glycine, while the MEV micrographies of the sample from urea showed globular grains with medium particle size relatively smaller than those observed for the calcined sample from the maleic anhydride. As regards the calcined samples from maleic anhydride showed higher porosity than the others, suggesting a higher gases evolution during the combustion process. Charge and discharge tests from the samples obtained by glycine fuel $\left(750{ }^{\circ} \mathrm{C} 4 \mathrm{~h}\right)$ presented the highest experimental specific capacities of $115 \mathrm{~mA} \mathrm{~h} \mathrm{~g}^{-1}$ and $92 \%$ of retention after 10 cycles. Thus, the nature of the fuel agent influences on both morphological and structural characteristics of the sintered oxides, affecting the electrochemical properties of the material and consequently, its applicability as positive electrodes in lithium ion batteries.

\section{Acknowledgements}

This work was supported by FAPEMIG (grants APQ 2279/10) and Rede Mineira de Química. The authors thank the scholarship PIBIC/UFU (grants 2011-EXA028).

Nova. 2002; 25:287-289. http://dx.doi.org/10.1590/S010040422002000200017

4. Guyomard D and Tarascon JM. The carbon $\mathrm{Li}_{1+\mathrm{X}} \mathrm{Mn}_{2} \mathrm{O}_{4}$ system. Solid State Ionics. 1994; 69:202. http://dx.doi. org/10.1016/0167-2738(94)90412-X

5. Pesquero NC, Bueno PR, Varela JA and Longo E. Materiais cerâmicos de inserção aplicados a baterias de íons lítio. Cerâmica. 2008; 54:233-235. http://dx.doi.org/10.1590/S036669132008000200014 
6. Yang W, Zhang G, Xie J, Yang L and Liu Q. A combustion method to prepare spinel phase $\mathrm{LiMn}_{2} \mathrm{O}_{4}$ cathode materials for lithium ion batteries. Journal of Power Sources. 1999; 81:412415. http://dx.doi.org/10.1016/S0378-7753(99)00219-0

7. Oliveira F. F. Síntese por combustão de pós de $\mathrm{SrBi}_{2} \mathrm{TaO}_{9}$, produção de corpos cerâmicos e sua caracterização quanto à microestrutura e propriedades elétricas. [Dissertação]. Porto Alegre: Universidade Federal do Rio Grande do Sul; 2010.

8. Jain SR, Adiga K and Verneker PV. A New Approach to Thermochemical Calculations of Condensed Fuel-Oxidizer Mixtures. Combustion and Flame. 1981; 40:71-79. http:// dx.doi.org/10.1016/0010-2180(81)90111-5

9. Hwang C-C, Wu T-Y, Wan J and Tsai J-S. Development of a novel combustion synthesis method for synthesizing of ceramic oxide powders. Material Science \& Enginnering. 2004; 111:4956. http://dx.doi.org/10.1016/j.mseb.2004.03.023
10. Cullity BD. Elements of X-ray difraction. Reading. Massachussets: Addison Wesley Publishing Company; 1967. $331 \mathrm{p}$.

11. Taniolo JC. Influência da razão combustível-oxidante nas características de óxidos nanoestruturados sintetizado por combustão em solução. [Dissertação]. Porto Alegre: Universidade Federal do Rio Grande do Sul; 2009.

12. Lu C and Fey GT. Nanocrystalline and long cycling $\mathrm{LiMn}_{2} \mathrm{O}_{4}$ cathode material derived by solution combustion method for lithium ion batteries. Journal of Physics and Chemistry of Solids. 2006. 67:756-761. http://dx.doi.org/10.1016/j. jpcs.2005.11.008

13. Zhu C, Nobuta A, Saito G, Nakatsugawa I and Akiyama T. Solution combustion synthesis of $\mathrm{LiMn}_{2} \mathrm{O}_{4}$ fine powders for lithium ion batteries. Advanced Powder Technology. 2013. http://dx.doi.org/10.1016/j.apt.2013.05.015 